\title{
FENTON REACTION DRIVEN BY IRON LIGANDS
}

\author{
PABLO SALGADO ${ }^{1,2}$, VICTORIA MELIN ${ }^{1,2}$, DAVID CONTRERAS ${ }^{1,2 *}$, YANKO MORENO ${ }^{I}$ AND \\ HECTOR D. MANSILLA .
}

\author{
${ }^{I}$ Analitycal and Inorganic Chemistry department, Faculty of Chemical Sciences, Universidad de Concepción. Concepción, Chile. \\ ${ }^{2}$ Biotechnology Center, Universidad de Concepción. Concepción, Chile \\ ${ }^{3}$ Organic Chemistry department, Faculty of Chemical Sciences, Universidad de Concepción. Concepción, Chile.
}

(Received: July 31, 2013 - Accepted: October 7, 2013)

\begin{abstract}
One of the most important sources of reactive oxygen species (ROS) in biological systems is the Fenton reaction. In this, the $\mathrm{Fe}^{2+}$ or $\mathrm{Fe}^{3+}$ reacts with $\mathrm{H}_{2} \mathrm{O}_{2}$ to produce ROS as the hydroxyl radical $(\cdot \mathrm{OH})$, superoxide radical $\left(\mathrm{O}_{2}^{\cdot}\right)$ and singlet oxygen $\left({ }^{1} \mathrm{O}_{2}\right)$.

The main ROS, responsible for the high oxidizing power of the Fenton reaction, is not clear. Some authors claim that the principal reactive species is $\mathrm{OH}$, while others propose a ferryl specie $\left(\mathrm{Fe}^{4+} \text { or }[\mathrm{FeO}]^{2+}\right)^{(1,2)}$. Recently, have been proposed that the kind of reaction species produced depends mainly of $\mathrm{pH}$ and the iron composition of the coordination sphere. This is highlighted for $\mathrm{Fe}^{3+}$, because in mono and (some) bis-complexes $\mathrm{Fe}^{3+}$ is reduced to $\mathrm{Fe}^{2+}$ and there are some positions occupied by water or hydroxide ligands, readily to be exchanged by $\mathrm{H}_{2} \mathrm{O}_{2}$. On the other hand, in tris-complexes there are not any positions occupied by water or hydroxide, avoiding the formation of peroxo-complexes, necessary for Fenton or Fenton like reaction.

The 1,2-dihydroxybenzenes (DHBs) have been described as modulators of Fenton reaction. The DHBs driven Fenton reaction have been used for environmental applications as an advanced oxidation process. Furthermore, these systems participate in different biological process, as the wood biodegradation by fungi and oxidative stress in neurodegenerative diseases.

In this review, the effect of 1,2-dihydroxybenzenes on the activated species production by the Fenton and Fenton like reaction will be discussed and its participation in different systems.
\end{abstract}

KEYWORDS Fenton reaction, iron ligands, ROS

\section{ROS generated by Fenton reaction}

The Fenton reaction was described by H.J.H. Fenton en 1894. Fenton was interested on the develop of a colored test for tartaric acid determination. For this, $\mathrm{H}_{2} \mathrm{O}_{2}$ was utilized catalyzed by $\mathrm{FeSO}_{4}$ salt (Fenton's reagent ${ }^{(3)}$. The mechanism of this reaction was proposed by Haber y Weiss at $1934^{(4)}$. This includes the hydroxyl radical $(\cdot \mathrm{OH})$ participation(1). This compound is the most reactive ROS (reactive oxygen specie) known ${ }^{(5)}$, have a standard redox potential of $2,8 \mathrm{~V}^{(2)}$ and consequently a low selectivity.

$$
\mathrm{Fe}^{2+}+\mathrm{H}_{2} \mathrm{O}_{2} \rightarrow \mathrm{Fe}^{3+}+\cdot \mathrm{OH}+\mathrm{OH}^{-}
$$

The $\mathrm{Fe}^{3+}$ reacts with $\mathrm{H}_{2} \mathrm{O}_{2}$ producing perhydroxyl radical $\left(\mathrm{HO}_{2} \cdot\right)$. This reaction is named "Fenton like" (2). The $\mathrm{HO}_{2}$ ', presents lower oxidant capacity than others ROS, but participate in the $\mathrm{Fe}^{3+}$ reduction to $\mathrm{Fe}^{2+}$ (3) to keep the $\cdot \mathrm{OH}$ production by (1).

$$
\begin{aligned}
& \mathrm{Fe}^{3+}+\mathrm{H}_{2} \mathrm{O}_{2} \rightarrow \mathrm{Fe}^{2+}+\mathrm{HO}_{2} \cdot+\mathrm{H}^{+} \\
& \mathrm{HO}_{2}+\mathrm{Fe}^{3+} \rightarrow \mathrm{O}_{2}+\mathrm{H}^{+}+\mathrm{Fe}^{2+}
\end{aligned}
$$

Is highlighted that Fenton reaction $\left(\mathrm{k}=76 \mathrm{M}^{-1} \mathrm{~s}^{-1}\right)(1)$ is four magnitude orders faster than Fenton like reaction $\left(\mathrm{k}=0.01 \mathrm{M}^{-1} \mathrm{~s}^{-1}\right)(2)^{(6)}$.

\section{Iron speciation and Fenton reaction}

The reactivity of Fenton reaction is $\mathrm{pH}$ dependent ${ }^{(t, 7)}$. There are different approach to explain this effect ${ }^{(l, 2,7-9)}$. Moffet and $\mathrm{Zika}^{(10)}$ determine different reaction rates for Fenton reaction from $\left[\mathrm{Fe}^{2+}\right]$ and $[\mathrm{Fe}(\mathrm{OH})]^{+}$. Morgan and Lahav $^{(I I)}$, determine that the constant rate for $[\mathrm{Fe}(\mathrm{OH})]^{+}$is $9.2 \times 10^{4}$ times higher than $\left[\mathrm{Fe}^{+2}\right]$ rate constant. However, the concentration of $[\mathrm{Fe}(\mathrm{OH})]^{+}$is $2.8 \times 10^{6}$ times lower than $\left[\mathrm{Fe}^{2+}\right]$ concentration at $\mathrm{pH} 3.0$ and $2.8 \times 10^{5}$ at $\mathrm{pH}$ 4.0 (figure 1-inset). This mean that $[\mathrm{Fe}(\mathrm{OH})]^{+}$is the most reactive specie for Fenton reaction but its concentration is very lower to be main specie involves in Fenton reaction. Thus, both species are involved in Fenton reaction but $\left[\mathrm{Fe}^{2+}\right]$ is the main one (specially at low $\mathrm{pH}$ ). The $[\mathrm{Fe}(\mathrm{OH})]^{+}$reach it maximum value at $\mathrm{pH}=10$ (Figure 1) and start to increase from $\mathrm{pH}=4$ (Figure 1-inset).

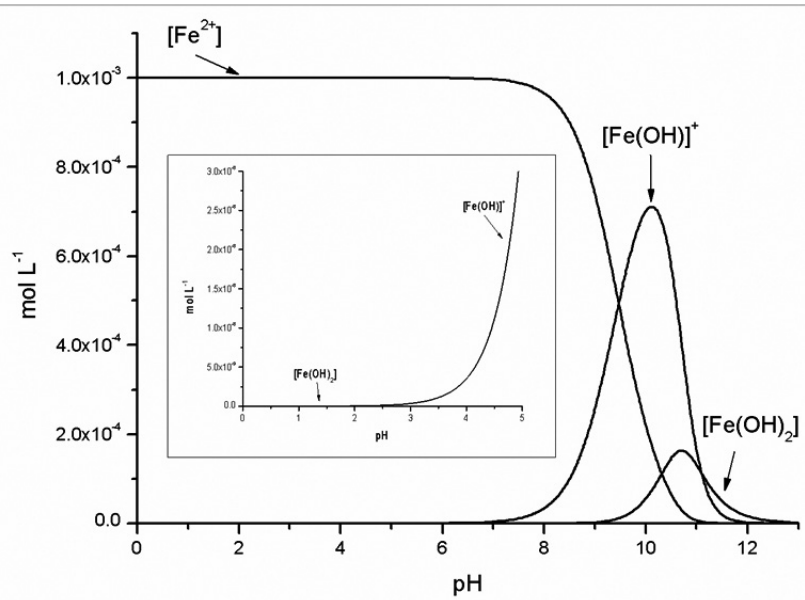

Figure 1. Speciation of a $\mathrm{Fe}\left(\mathrm{NO}_{3}\right)_{2} 1.00 \times 10^{-3} \mathrm{~mol} \mathrm{~L}^{-1}$ and $\mathrm{H}_{2} \mathrm{O}_{2} 1.00 \mathrm{~mol}$ $\mathrm{L}^{-1}$ solution at different $\mathrm{pH}$.

Nevertheless, at this $\mathrm{pH}$ value, all the $\mathrm{Fe}$ soluble species are unstable according to Pourbaix diagram (Figure 2). In consequence, a Fenton reaction is not possible at this conditions. The highest reactivity of $[\mathrm{Fe}(\mathrm{OH})]^{+}$have been associated with its ligand lability to exchange $\mathrm{H}_{2} \mathrm{O}$ by $\mathrm{H}_{2} \mathrm{O}_{2}$ to form a peroxocomplex $[\mathrm{Fe}(\mathrm{OOH})]^{+(12)}$, postulated as an intermediary of the Fenton reaction ${ }^{(7)}$. 


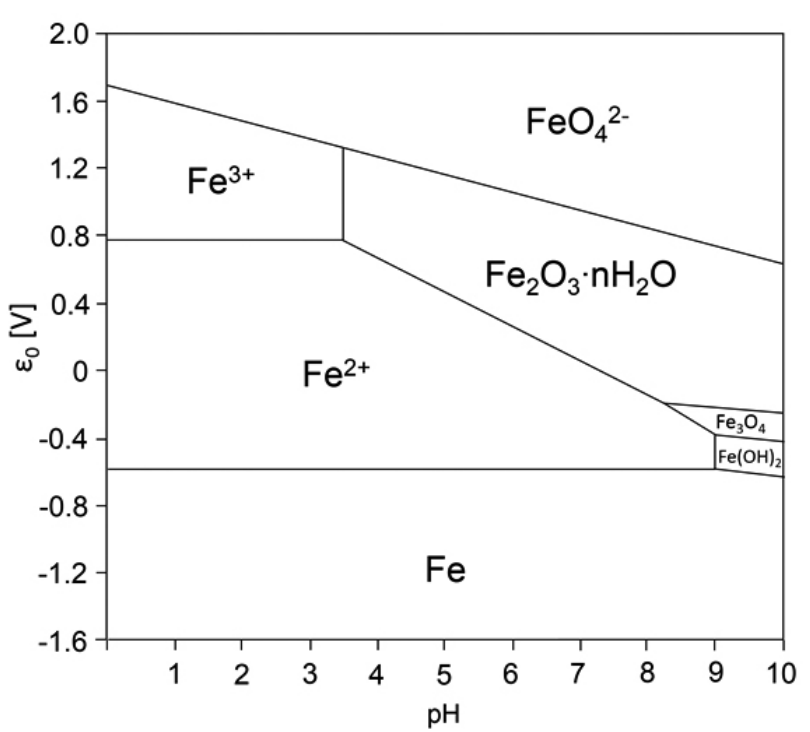

Figure 2. Iron Pourbaix diagram modified from Beverskoog et al $1996^{(13)}$

In this compound $\mathrm{Fe}^{2+}$ is oxidized through a inner sphere mechanisms (Figure 3). Keenan et al. ${ }^{(14)}$ propose a hydrogen peroxo-complex $\left[\mathrm{Fe}\left(\mathrm{H}_{2} \mathrm{O}_{2}\right)\right]^{2+}$ as intermediary.

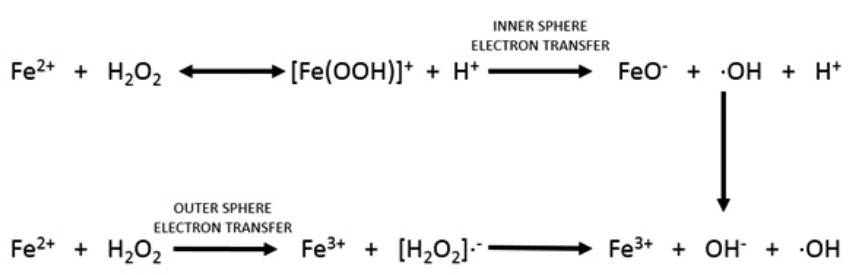

Figure 3. Inner sphere and outer sphere mechanism for Fenton reaction, modified from Mwebi et al $2005^{(15)}$.

The optimal $\mathrm{pH}$ for Fenton reaction is close to $3.0^{(1,2)}$. The reason of this value can not be explained by $\mathrm{Fe}$ (II) speciation; because until $\mathrm{pH}$ close to 4, the main soluble specie is $\left[\mathrm{Fe}^{2+}\right]$ and the rate of Fenton reaction increases with the $\mathrm{pH}^{(1)}$. After $\mathrm{pH}=4$, almost all the $\mathrm{Fe}$ species are insoluble like $\mathrm{Fe}_{2} \mathrm{O}_{3}$ (Figure 2) or other colloidal hydroxide compounds. Thereby, the Fenton reaction (without Fe ligands), decrease its reactivity after $\mathrm{pH}=4$. The reason for the optimal $\mathrm{pH}$ value for Fenton reaction can be explained by the $\mathrm{Fe}$ (III) speciation. The $\mathrm{Fe}^{3+}$ speciation is shown in Figure 4. The highest reactivity of Fenton reaction (at $\mathrm{pH}=3)^{(17)}$ is related to $[\mathrm{Fe}(\mathrm{OH})]^{2+}$ specie ${ }^{(18)}$. This specie could be related with the lability of water to be exchanged by $\mathrm{H}_{2} \mathrm{O}_{2}$ in a similar way than for $\mathrm{Fe}^{2+}$ species(4). Pignatello et al ${ }^{(19)}$ and Ensing et $\mathrm{al}^{(20)}$ propose the peroxo-complex $\left([\mathrm{FeOOH}]^{2+}\right.$ ) participation in Fenton reaction (5). Gallard et al ${ }^{(2 l)}$, quantify this complex by a spectrophotometric method. From the equilibrium constants reported by Gallard et $\mathrm{al}^{(2 l)}$ and the NIST Database 46 Version 8 , a Fe(III) speciation diagram was generated (Figure 4).

$$
\begin{gathered}
{\left[\mathrm{FeOH}^{2+}+\mathrm{H}_{2} \mathrm{O}_{2} \rightarrow[\mathrm{Fe}(\mathrm{OH})(\mathrm{OOH})]^{+}\right.} \\
\mathrm{Fe}^{3+}+\mathrm{H}_{2} \mathrm{O}_{2} \rightarrow[\mathrm{He}(\mathrm{OOH})]^{2+}+\mathrm{H}^{+}
\end{gathered}
$$

Figure 4 shown the speciation of soluble species of $\mathrm{Fe}\left(\mathrm{NO}_{3}\right)_{3} 1.00 \times 10^{-3}$ mol L-1 presence of $\mathrm{H}_{2} \mathrm{O}_{2} 1.00 \mathrm{~mol} \mathrm{~L}^{-1}$ from $\mathrm{pH} 0$ to 5 . In this plot is highlighted the maximum concentration of $[\mathrm{Fe}(\mathrm{OH})]^{2+}$ and $[\mathrm{Fe}(\mathrm{OOH})]^{2+}$ species at $\mathrm{pH}$ close to 3.0 (the optimum $\mathrm{pH}$ value for Fenton reaction). The rate-limiting step in Fenton reaction is the $[\mathrm{Fe}(\mathrm{OOH})]^{2+}$ or $[\mathrm{Fe}(\mathrm{OH})(\mathrm{OOH})]^{+}$decomposition $(6$, $7)^{(21)}$. The effective rate constant for both is $2.7 \times 10^{-3} \mathrm{~s}^{-1}$. The individual rate constants are unknown ${ }^{(I)}$.

$$
\begin{gathered}
{[\mathrm{Fe}(\mathrm{OOH})]^{2+} \rightarrow \mathrm{Fe}^{2+}+\cdot \mathrm{OOH}} \\
{[\mathrm{Fe}(\mathrm{OH})(\mathrm{OOH})]^{+} \rightarrow \mathrm{Fe}^{2+}+\cdot \mathrm{OOH}+\mathrm{OH}^{-}}
\end{gathered}
$$

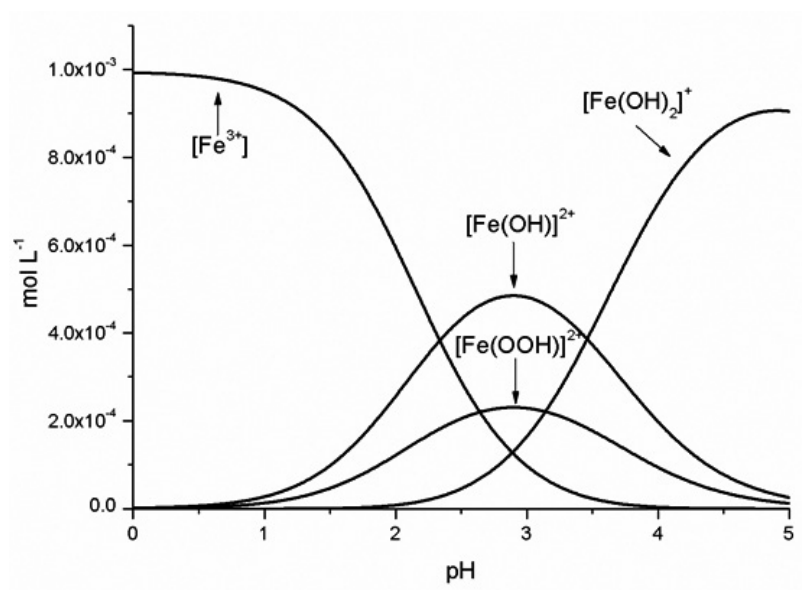

Figure 4. Speciation of a $\mathrm{Fe}\left(\mathrm{NO}_{3}\right)_{3} 1.00 \times 10^{-3} \mathrm{~mol} \mathrm{~L}^{-1}$ and $\mathrm{H}_{2} \mathrm{O}_{2} 1.00 \mathrm{~mol}$ $\mathrm{L}^{-1}$ solution at different $\mathrm{pH}$.

The reaction 6 and 7 are sources of $\mathrm{Fe}(\mathrm{II})$ and $\mathrm{HO}_{2}$, which reduce $\mathrm{Fe}$ (III) to $\mathrm{Fe}(\mathrm{II})\left(\mathrm{k}=2 \times 10^{3} \mathrm{~mol} \mathrm{~L}^{-1} \mathrm{~s}^{-1}\right)$. In this rate-limiting step, the $\mathrm{Fe}(\mathrm{II})$ is regenerated and the Fenton reaction can maintain the $\cdot \mathrm{OH}$ by reaction (1).

\section{3. $\mathrm{Fe}(\mathrm{IV})$ and singlet Oxygen in Fenton reaction}

There are experimental evidence for ferryl species formation $\left([\mathrm{FeO}]^{2+}\right)$ in Fenton reaction. Some authors propose this compound as the oxidant in Fenton reaction more than $\cdot \mathrm{OH}^{(22,23)}$. The main experimental evidence is based on the capacity of Fenton reaction to oxidate substrates in the presence of $\cdot \mathrm{OH}$ quenchers ${ }^{(24-26)}$. Ferryl intermediary in Fenton reaction was proposed by Brain y Gorin ${ }^{(27)}$, according to (8).

$$
\mathrm{Fe}^{2+}+\mathrm{H}_{2} \mathrm{O}_{2} \rightarrow[\mathrm{FeO}]^{2+}+\mathrm{H}_{2} \mathrm{O}
$$

Some authors propose the coexistence of $\cdot \mathrm{OH}$ and $[\mathrm{FeO}]^{2+}$ on Fenton reaction. For this there are experimental evidence based on spin trapping ${ }^{(28)}$, UV/Vis stopped-flow kinetic(29), pulse radiolysis on peroxo-complexes in aqueous solution ${ }^{(30)}$ and chemiluminescence data $^{(31,32)}$.

Ferryl species have been detected in complexes that stabilize Fe(IV) ${ }^{(33,34)}$, in enzymatic reaction of peroxidases ${ }^{(35)}$ and heterogeneous catalysis by zero valent iron ${ }^{(36,37)}$. Some authors ${ }^{(38-41)}$, have developed techniques to determine selectively the presence of $[\mathrm{FeO}]^{2+}$ or $\cdot \mathrm{OH}$ based on the reactivity again a substrate (Figure 5).
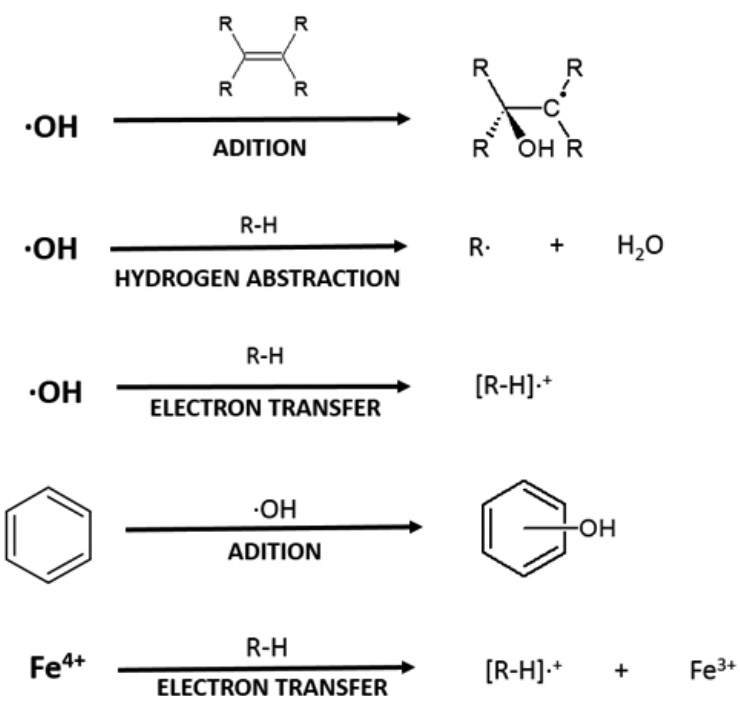

Figure 5. Hydroxyl radical and ferryl reactivity against organic substrates

There are several publications that probe the Haber-Weiss mechanisms of 
Fenton reaction (mediated by $\cdot \mathrm{OH})^{(28,42)}$ and others that probe the Bray-Gorin mechanism of Fenton reaction (mediated by $\left.[\mathrm{FeO}]^{2+}\right)^{(43,44)}$. However, in some of these publications have been proposed the formation of different oxidant species in dependence of reaction conditions $(\mathrm{pH}$, reagents concentration, redox potential, etc. $)^{(45-49)}$. Lee et $\mathrm{al}^{(48)}$ and Bataineh et $\mathrm{al}^{\left({ }^{(4)}\right)}$ propose the $\mathrm{pH}$ as the main factor but these results are not concluding.

Recently, the singlet oxygen $\left({ }^{1} \mathrm{O}_{2}\right)$ have been postulated between the oxidant compounds generated by Fenton reaction ${ }^{(50,5 I)}(9-11)$. This species is stronger oxidant than triplet oxygen ${ }^{(52,53)}$.

$$
\begin{aligned}
& \mathrm{HO}_{2}+\mathrm{HO}_{2} \cdot \rightarrow \mathrm{H}_{2} \mathrm{O}_{2}+{ }^{1} \mathrm{O}_{2} \\
& \mathrm{OH}^{+}+\mathrm{OH}^{2} \rightarrow \mathrm{H}_{2} \mathrm{O}+1 / 2^{1} \mathrm{O}_{2} \\
& \mathrm{HO}_{2} \cdot+\mathrm{OH} \rightarrow \mathrm{H}_{2} \mathrm{O}+{ }^{1} \mathrm{O}_{2}
\end{aligned}
$$

The effect of $\mathrm{pH}$ in the in the iron species, the Fe(II) recycling mechanisms, limiting step and oxidant species generated are summarized in Figure 6.

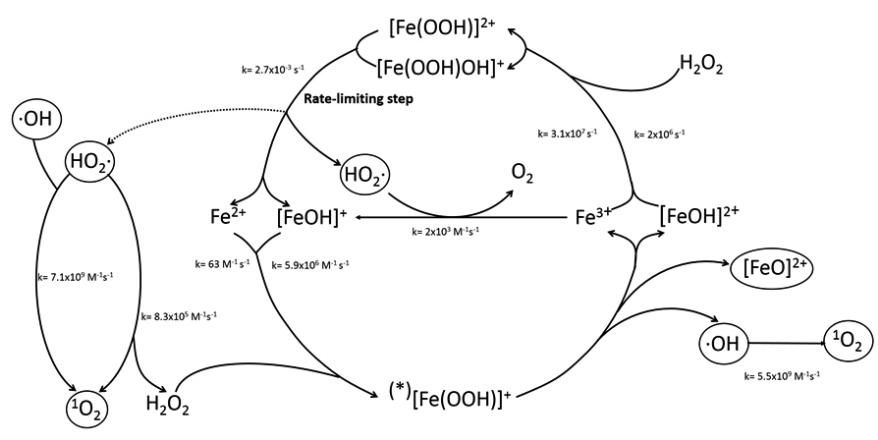

Figure 6. Redox cycle of Fenton reaction based in kinetic values from literature $^{(7,54-56) \text {. }}$

The Fenton reaction can be explained as a substrate oxidation by $\mathrm{H}_{2} \mathrm{O}_{2}$ catalyzed by $\mathrm{Fe}(\mathrm{II})$ establishing a redox cycle . Figure 6, shown how $\mathrm{H}_{2}^{2} \mathrm{O}_{2}$ (relative stable) is transform in very reactive species that reacts again substrates. Thus, soluble Fe(II) species bind $\mathrm{H}_{2} \mathrm{O}_{2}$ being obtained $[\mathrm{Fe}(\mathrm{OOH})]^{+}$, this decomposes to $[\mathrm{FeO}]^{+2}$ and $\cdot \mathrm{OH}$. This last, can disproportionate to ${ }^{1} \mathrm{O}_{2}$. This is the main oxidant production stage in the Fenton reaction, after a $\mathrm{Fe}(\mathrm{II})$ recycling stage have to be established from $\mathrm{Fe}(\mathrm{III})$ soluble species. These species, are binding by $\mathrm{H}_{2} \mathrm{O}_{2}$ (reactive in excess) to peroxocomplexes in a fast step. Later, these complexes disproportionate to $\mathrm{Fe}(\mathrm{II})$ and $\mathrm{HO}_{2} \cdot$ in the rate limiting step. From this step, $\mathrm{Fe}(\mathrm{II})$ is recuperated directly and $\mathrm{HO}_{2}$. can reduce another $\mathrm{Fe}(\mathrm{III})$ to $\mathrm{Fe}$ (II). The $\mathrm{HO}_{2} \cdot$ can reacts with $\cdot \mathrm{OH}$ to ${ }^{1} \mathrm{O}_{2}$ in a secondary reaction, because both radicals are in low concentration.

\section{Ligands effects on Fenton Reaction}

The speciation of $\mathrm{Fe}^{2+}$ and $\mathrm{Fe}^{3+}$ hydroxide-complexes ( $\mathrm{pH}$ dependent) are very important to define the reactivity of the Fenton and Fenton like systems. The importance of the iron coordination sphere constitution on Fenton reactivity can be applied for others iron ligands. In this way, some authors have been postulated that the coordination number of some organic ligands are mainly $\mathrm{pH}$ depending than concentration depending ${ }^{(57,58)}$.

Sun and Pignatello ${ }^{(59)}$ propose that ligands can modify the reactivity of Fenton's systems by three ways: (I) modification of redox properties of the metal, (II) create a labile coordination site that could be occupied by $\mathrm{H}_{2} \mathrm{O}_{2}$, (III) competence with the substrate for the oxidant compounds.

According to way (I), organic ligands at higher $\mathrm{pH}$ values can chelate iron completely ${ }^{(60-62)}$, changing the redox potential of $\mathrm{Fe}^{2+} / \mathrm{Fe}^{3+}$ pair $\left(\mathrm{E}^{\circ}=+0.771 \mathrm{~V}\right)$ ${ }^{(63)}$. Considering the way (II) and highlighting that the first transition period are labile, following a dissociative mechanisms $\left(\mathrm{S}_{\mathrm{N}} 1\right)^{(64)}$. The $\mathrm{Fe}^{3+}$ complexes can shows several labile positions to be substituted by $\mathrm{H}_{2} \mathrm{O}_{2}$ and, if the ligand is redox active, reduce $\mathrm{Fe}^{3+(65,60)}$. Devanur et al. ${ }^{(67)}$, synthetized a deferiprone biscomplex. This compound have two free coordination sites for water that can be replaced by $\mathrm{H}_{2} \mathrm{O}_{2}$ producing a peroxo-complex and releasing $\cdot \mathrm{OH}$. This is not true for other ligands, Strlič y col. ${ }^{\left({ }^{(8)}\right)}$ determine that in 1,2-dihydroxybenzenes (DHB) bis-complexes of iron is not possible the $\mathrm{H}_{2} \mathrm{O}_{2}$ incorporation in the coordination sphere. In this way this ligand acts as an antioxidant. However, Kawabata et al. ${ }^{(69)}$ determine the inclusion of $\mathrm{H}_{2} \mathrm{O}_{2}$ in the coordination sphere in DHB iron complexes and the production of oxidant species.
Tris-complexes show an antioxidant behavior, because the complete $\mathrm{Fe}^{3+}$ chelation. This avoids the access of $\mathrm{H}_{2} \mathrm{O}_{2}$ to the coordination sphere. Thus the Fenton reaction is inhibit ${ }^{(70)}$. The complete $\mathrm{Fe}^{3+}$ chelation is improved at high $\mathrm{pH}$ values.

The prooxidant ability of ligands through a Fenton reaction, have been observed in several compounds. Between these are highlighted 2,4-dimethylaniline ${ }^{(4)}$, EDTA, DTPA and desferal ${ }^{(7)}$, humic acids $^{(72)}$, oleuropein $^{(73)}$, malonic acid, oxalic acid ${ }^{(74)}$, ascorbic acid ${ }^{(7)}$ and $\mathrm{DHBs}^{(76)}$. The prooxidant ability has been associated to the $\mathrm{Fe}^{3+}$ reduction to $\mathrm{Fe}^{2+}$ and the establish of a redox cycle ${ }^{(77)}$. A similar effect have been describe for $\mathrm{Cu}(\mathrm{I})$ Fenton reaction ${ }^{(78)}$

The antioxidant ability of iron ligands has been associated to radical scavenger, radical deactivation and inhibition of the initiation reaction by metal chelation. Between these are highlighted ferulic acid ${ }^{(79)}$, carotenoids ${ }^{(80)}$, tannic $\operatorname{acid}^{(81)}, \mathrm{DHB}^{(82)}$, flavonoids ${ }^{(83)}$.

Several ligands, known for their antioxidant properties, have shown prooxidant activity, and vice versa ${ }^{[68]}$. This dual behavior have been attributed to reaction variables like reagents concentration and $\mathrm{pH}^{(84,85)}$. Between these are highlighted flavonoids ${ }^{(8)}$, carotenoids, ascorbic acid, tocopherols ${ }^{(87)}$ and DHB $^{(88-9)}$.

The DHB have special interest because its participation in several biological systems like metabolic pathways in mammals, fungal mechanisms for wood biodegradation, etc. ${ }^{(I, 92-94)}$.

\section{DHB driven Fenton reaction}

The Fenton reaction driven by DHB has been studied in different systems like metabolic pathways in biological systems ${ }^{(95-97)}$ and advanced oxidation process (AOPs) to water or wastewater treatment ${ }^{77,89,98,99)}$. This phenomenon has been explained by several authors through distinct reaction pathways: (I) DHBs can form complexes with $\mathrm{Fe}^{3+}$ and then reduce it to $\mathrm{Fe}^{2+(100)}$. In this process the DHB is oxidized to the corresponding semiquinone $\mathrm{e}^{(77,10 I)}$, whereby the pKa of the hydroxyl groups has high importance because the ligand is the deprotonated $\mathrm{DHB}^{(102)}$. The semiquinone can reduce another $\mathrm{Fe}^{3+}$ to $\mathrm{Fe}^{2+}$ forming the corresponding quinone (Figure 7) ${ }^{(102)}$. Evidence of the formation of semiquinone- $\mathrm{Fe}^{2+}$ complex, has been found through Mössbauer spectroscopy ${ }^{(6)}$ and by magnetic moment measure ${ }^{(103)}$. (II) Semiquinone is also an oxidant specie, therefore in addition to oxidize substrates may also react with $\mathrm{H}_{2} \mathrm{O}_{2}^{(104,}$ 105)(12). (III) Peroxo-complex intermediaries stabilization ${ }^{(25,100)}$. (IV) "Redox cycle" (quinone-hydroquinone). This amplifies the reduction of $\mathrm{Fe}^{3+}$ to $\mathrm{Fe}^{2+}$ through hydroxy hexadienyl products formed in the oxidation of 1,2-DHB by - $\mathrm{OH}$ radicals which also possess reductive capacity. It is also known that while quinones are reduced may cause oxidation of other molecules involved in the redox cycle like other $1,2-\mathrm{DHB}^{(107,108)}$. The quinones can also be oxidized to $\mathrm{CO}_{2}$ while reducing $\mathrm{Fe}^{3+(109)}$. (V) $\mathrm{O}_{2}$ a $\mathrm{O}_{2} \cdot-$ reduction by semiquinone. $\mathrm{O}_{2}{ }^{--}$can also react with $\mathrm{H}_{2} \mathrm{O}_{2}$ to give $\cdot \mathrm{OH}$ radicals, $\mathrm{O}_{2} \mathrm{y} \mathrm{OH}^{-(110,1 I I)}$.

In the DHBs ligands are biological catecholamines (dopamine, epinephrine and norepinephrine). These compounds are high importance in the human physiology and physiopathology. Thus, these compounds have been related with the etiology and development of Parkinson's disease ${ }^{(I 12-114)}$, stress-induced arrhythmias, cardiopathies ${ }^{(115)}$ and inflammatory damage caused by chronic stress $^{(I I)}$.

Catecholamines form complexes with $\mathrm{Fe}^{3+}$ by the catecholate group. The coordination number is $\mathrm{pH}$ dependent ${ }^{(I I)}$. At acidic $\mathrm{pH}$ mainly monocomplex are formed this are very unstable since quickly reduce $\mathrm{Fe}^{3+}$ to $\mathrm{Fe}^{2+}$ by inner-sphere mechanism. At neutral $\mathrm{pH}$ bis-complexes are formed, this are more stable than mono-complex. At basic $\mathrm{pH}$ the stable tris-complexes are formed $^{(118)}$

Recent results (unpublished) are showed that catecholamines are able to drive a Fenton reaction in a similar way than other $\mathrm{DHB}^{(18,76)}$. These systems are able to degrade recalcitrant compounds. However, the degradation is closely $\mathrm{pH}$ related and only is performed by the mono-complexes. 


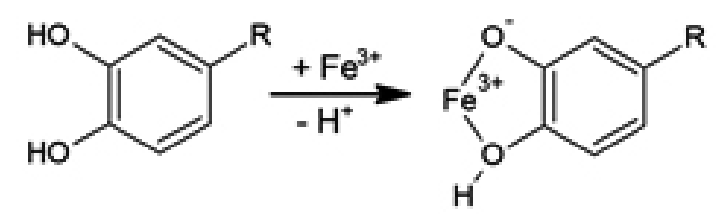

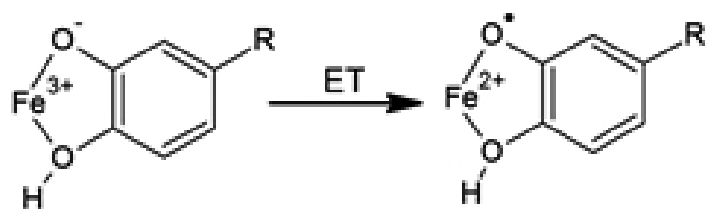<smiles>[R]c1ccc2c(c1)[O+][P+](CC)[O+]O2</smiles><smiles>[R]c1ccc2c(c1)[O+][O+][C-]2CC</smiles><smiles>[R]c1ccc([O-])c([O-])c1</smiles><smiles>[R]c1ccc([O-])c([O])c1</smiles><smiles>[R]c1ccc([O])c([O])c1</smiles><smiles>[R]c1ccc([O])c([O])c1</smiles><smiles>[R]C1=CC(=O)C(=O)C=C1</smiles>

\section{ET: Electron Transfer}

Figure 7: $\mathrm{Fe}^{3+}$ reduction mechanisms by DHBs.

$$
\mathrm{SQ} \cdot+\mathrm{H}_{2} \mathrm{O}_{2} \rightarrow \mathrm{Q}+\cdot \mathrm{OH}+\mathrm{OH}^{-}
$$

\section{CONCLUSION}

There are several controversial reports about the kind and amount of oxidant species generated by a Fenton reaction. Some authors relate this variability with the reaction conditions. Notwithstanding these differences, there are accordance about the importance of the ligands in the coordination sphere of $\mathrm{Fe}^{2+}$ (or $\mathrm{Fe}^{3+}$ in Fenton-Like) for the reactivity of a Fenton system. The prooxidant and antioxidant effect of the ligands depends of the nature and coordination number. These factors in turn depend on the reaction conditions ( $\mathrm{pH}$, reagents concentration, etc.). The DHBs have special importance because are involve in several biological systems and AOPs, also this compound can increase, induce or inhibit a Fenton reaction by several pathways depending of the reaction conditions. The understanding of these systems can be very important to modify biological process (fungal wood biodegradation, neurological diseases, etc.) and develop AOP technologies.

\section{ACKNOWLEDGEMENTS}

The authors thanks to Dr. Wilko Verweij by the free license of the software "CHEAQS pro V. 2004.1" (http://home.tiscali.nl/cheaqs) performed to determine all the speciation calculations. The authors also thanks the financial support provided from FONDECYT (Grant no. 1131101 and Grant no. 1110606), FONDAP Solar Energy Research Center, SERC-Chile (Grant 15110019), ANILLO (ACT 130). Pablo Salgado and Victoria Melin thanks to CONICYT PhD fellowship.

\section{REFERENCES}

1. J. J. Pignatello, E. Oliveros, A. MacKay, Critical Reviews in Environmental Science and Technology 36, 1 (2006).

2. S. I. Brillas Enric, Oturan Mehmet, Chemical Reviews 109, 6570 (2009).

3. H. J. H. Fenton, Journal of the Chemical Society, Transactions 65, 899 (1894).

4. F. Haber, J. Weiss, Proceedings of the Royal Society of London. Series A, Mathematical and Physical Sciences 147, 332 (1934).

5. K. Keyer, A. Strohmeier, J. A. Imlay, Journal of Bacteriology 177, 6782 (1995).

6. R. Chen, J. J. Pignatello, Environmental Science \& Technology 31, 2399 (1997).

7. H. Gallard, J. de Laat, B. Legube, New Journal of Chemistry 22, 263 (1998).

8. C. F. Wells, M. A. Salam, Journal of the Chemical Society A: Inorganic, Physical, Theoretical 203, 24 (1968).

9. C. F. Wells, M. A. Salam, Nature 205, 690 (1965).

10. J. W. Moffett, R. G. Zika, Environmental Science \& Technology 21, 804 (1987).

11. B. Morgan, O. Lahav, Chemosphere 68, 2080 (2007).

12. W. Szulbinski, Polish Journal of Chemistry 74, 109 (2000).

13. B. Beverskog, I. Puigdomenech, Corrosion Science 38, 2121 (1996).

14. C. Keenan, D. Remucal, L. Sedlak, Aquatic Redox Chemistry 1071, 177 (2011).

15. N. Mwebi, Fenton \& Fenton-like reactions: The nature of oxidizing intermediates involved. University of Maryland (College Park, Md.) Ph.D. Thesis, 160 (2005).

16. F. J. Millero, S. Sotolongo, Geochimica et Cosmochimica Acta 53, 1867 (1989).

17. C. M. Flynn, Chemical Reviews 84, 31 (1984).

18. D. Contreras, J. Freer, J. Rodríguez, International Biodeterioration \& Biodegradation 57, 63 (2006).

19. J. J. Pignatello, D. Liu, P. Huston, Environmental Science \& Technology 33, 1832 (1999).

20. B. Ensing, F. Buda, E. J. Baerends, The Journal of Physical Chemistry A 107, 5722 (2003)

21. H. Gallard, J. De Laat, B. Legube, Water Research 33, 2929 (1999).

22. D. R. Dufield, G. S. Wilson, R. S. Glass, C. Schöneich, Journal of Pharmaceutical Sciences 93, 1122 (2004).

23. W. Freinbichler, K. F. Tipton, L. D. Corte, W. Linert, Journal of Inorganic Biochemistry 103, 28 (2009).

24. P. Verma, P. Baldrian, J. Gabriel, T. Trnka, F. Nerud, Chemosphere 57, 1207 (2004).

25. S. Aleksei Ya, V. G. Isak, Russian Chemical Reviews 64, 1105 (1995).

26. F. Buda, B. Ensing, M. C. M. Gribnau, E. J. Baerends, Chemistry - A European Journal 9, 3436 (2003).

27. W. C. Bray, M. H. Gorin, Journal of the American Chemical Society 54, 2124 (1932).

28. I. Yamazaki, L. H. Piette, Journal of the American Chemical Society $\mathbf{1 1 3}$ 7588 (1991).

29. D. A. Wink, R. W. Nims, J. E. Saavedra, W. E. Utermahlen, P. C. Ford, Proceedings of the National Academy of Sciences 91, 6604 (1994).

30. M. L. Kremer, G. Stein, Transactions of the Faraday Society 55, 959 (1959).

31. X. Shen, J. Tian, J. Li, X. Li, Y. Chen, Free Radical Biology and Medicine 13, 585 (1992).

32. D. Contreras, Rodriguez, J., Salgado, P., Soto-Salazar, C., Qian, Y., Goodell, B., Inorganica Chimica Acta 374, 643 (2011).

33. A. L. Feig, S. J. Lippard, Chemical Reviews 94, 759 (1994).

34. O. Pestovsky, A. Bakac, Inorganic Chemistry 45, 814 (2005).

35. J. T. Groves, Journal of Inorganic Biochemistry 100, 434 (2006).

36. E. A. Jarvis, A. M. Chaka, Surface Science 601, 1909 (2007).

37. L. Kiwi-Minsker, D. A. Bulushev, A. Renken, Journal of Catalysis 219, 273 (2003).

38. S. H. Bossmann, E. Oliveros, S. Göb, S. Siegwart, E.P. Dahlen, L. Payawan, M. Straub, M. Wörner, A.M. Braun, The Journal of Physical 
Chemistry A 102, 5542 (1998).

39. D. O. Mártire, P. Caregnato, J. Furlong, P. Allegretti, M. C. Gonzalez, International Journal of Chemical Kinetics 34, 488 (2002).

40. O. Pestovsky, A. Bakac, Journal of the American Chemical Society 126, 13757 (2004)

41. F. Jacobsen, J. Holcman, K. Sehested, International Journal of Chemical Kinetics 30, 215 (1998).

42. J. Kiwi, A. Lopez, V. Nadtochenko, Environmental Science \& Technology 34, 2162 (2000).

43. M. L. Kremer, Physical Chemistry Chemical Physics. 1, 3595 (1999).

44. D. A. Wink, C. B. Wink, R. W. Nims, P. C. Ford, Environmental Health Perspectives 102, 11 (1994).

45. L. Deguillaume, M. Leriche, N. Chaumerliac, Chemosphere 60, 718 (2005).

46. S. H. Bossmann, E. Oliveros, M. Kantor, S. Niebler, A. Bonfill, N. Shahin, M. Worner, A.M. Braun, Water science and technology : a journal of the International Association on Water Pollution Research 49, 75 (2004).

47. C. K. Duesterberg, W. J. Cooper, T. D. Waite, Environmental Science \& Technology 39, 5052 (2005).

48. H. Lee, H.-J. Lee, D. L. Sedlak, C. Lee, Chemosphere 92, 652 (2013).

49. H. Bataineh, O. Pestovsky, A. Bakac, Chemical Science 3, 1594 (2012).

50. J. Cadet, T. Douki, J.-P. Pouget, J.-L. Ravanat, Singlet oxygen DNA damage products: Formation and measurement. Methods in Enzymology 319, 143 (2000).

51. A. S. Lucymara Agnez-Lima; Julliane Melo, Ana Helena Oliveira, Ana Rafaela Timoteo, Keronninn Lima-Bessa, Glaucia Martinez, Marisa Medeiros, Paolo Di Mascio, Rodrigo Galhardo, Carlos Menck, Mutation Research/Reviews in Mutation Research 751, 15 (2012).

52. L. Chao, G. Song, J.-M. Lin, TrAC Trends in Analytical Chemistry 25, 985 (2006).

53. D. B. Min, J. M. Boff, Comprehensive Reviews in Food Science and Food Safety 1, 58 (2002).

54. I. P. Ivanova, Trofimova, S.V., Piskarev, I.M., Aristova, N.A., Burhina, O.E., Soshnikova, O.O., Journal of Biophysical Chemistry 3, 88 (2012).

55. J. De Laat, T. Giang Le, Environmental Science \& Technology 39, 1811 (2005).

56. H. Gallard, J. De Laat, Chemosphere 42, 405 (2001).

57. R. C. Hider, Z. D. Liu, H. H. Khodr, Metal chelation of polyphenols. Methods in Enzymology 335, 190 (2001).

58. L. Zhou, R. J. Elias, Journal of Agricultural and Food Chemistry 60 , 2906 (2012).

59. Y. Sun, J. J. Pignatello, Journal of Agricultural and Food Chemistry 40 , 322 (1992).

60. M. Kumamoto, T. Sonda, K. Nagayama, M. Tabata, Bioscience, Biotechnology, and Biochemistry 65, 126 (2001).

61. L. Zhou, E. Ryan, Food Chemistry 138, 1503 (2013).

62. L. Mira, M. Fernandez, M. Santos, R. Rocha, M. Florencio, K. Jennings, Free Radical Research 36, 1199 (2002).

63. İ. Gülçin, Chemico-Biological Interactions 179, 71 (2009).

64. F. A. Cotton, G. Wilkinson, Advanced inorganic chemistry: a comprehensive text. (John Wiley \& Sons, 1966).

65. E. Graf, J. R. Mahoney, R. G. Bryant, J. W. Eaton, Journal of Biological Chemistry 259, 3620 (1984)

66. R. C. Hider, A. R. Mohd-Nor, J. Silver, I. E. G. Morrison, L. V. C. Rees, Journal of the Chemical Society, Dalton Transactions 0, 609 (1981).

67. L. D. Devanur, H. Neubert, R. C. Hider, Journal of Pharmaceutical Sciences 97, 1454 (2008)

68. M. Strlič, T. Radovič, J. Kolar, B. Pihlar, Journal of Agricultural and Food Chemistry 50, 6313 (2002).

69. T. Kawabata, V. Schepkin, N. Haramaki, R. S. Phadke, L. Packer, Biochemical Pharmacology 51, 1569 (1996).

70. Y. Kono, S. Kashine, T. Yoneyama, Y. Sakamoto, Y. Matsui, H. Shibata., Bioscience, Biotechnology, and Biochemistry 62, 22 (1998).

71. I. Šnyrychová, P. Pospíśil, J. Nauš, Photosynthesis Research 88, 323 (2006).

72. A. Georgi, A. Schierz, U. Trommler, C. P. Horwitz, T. J. Collins, F. D. Kopinke., Applied Catalysis B: Environmental 72, 26 (2007).

73. A. Mazziotti, F. Mazzotti, M. Pantusa, L. Sportelli, G. Sindona, Journal of Agricultural and Food Chemistry 54, 7444 (2006).

74. J. Ma, W. Ma, W. Song, C. Chen, Y. Tang, J. Zhao, Y. Huang, Y. Xu, L. Zang, Environmental Science \& Technology 40, 618 (2005).

75. M. J. Kang, S. S. Lee, H. C. Koh, Toxicology 294, 1 (2012).
76. D. Contreras, J. Rodríguez, J. Freer, B. Schwederski, W. Kaim, Journal of Biological Inorganic Chemistry. 12, 1055 (2007).

77. E. Mentasti, E. Pelizzetti, G. Saini, Journal of Inorganic and Nuclear Chemistry 38, 785 (1976)

78. R. Valenzuela, D. Contreras, C. Oviedo, J. Freer, J. Rodriguez, International Biodeterioration \& Biodegradation 61, 345 (2008).

79. N. Nenadis, H. Zhang, M. Tsimidou, Journal of Agricultural and Food Chemistry 51, 1874 (2003).

80. N. E. Polyakov, A. I. Kruppa, T. V. Leshina, T. A. Konovalova, L. D. Kispert, Free Radical Biology and Medicine 31, 43 (2001).

81. R. G. Andrade, L. T. Dalvi, J. Silva, G. Lopes, A. Alonso, M. HermesLima., Archives of Biochemistry and Biophysics 437, 1 (2005).

82. Y. Qian, B. Goodell, C. C. Felix, Chemosphere 48, 21 (2002).

83. M. Terashima, Y. Kakuno, N. Kitano, C. Matsuoka, M. Murase, N. Togo, R. Watanabe, S. Matsumura, Plant Cell Reports. 31, 291 (2012).

84. M. A. A. Mahmoud, V. S. Chedea, A. Detsi, P. Kefalas, Food Research International 51, 907 (2013).

85. A. Aguiar, A. Ferraz, International Biodeterioration \& Biodegradation 74, 61 (2012)

86. K. Macáková, P. Mladěnka, T. Filipský, M. Říha, L. Jahodáŕ, F. Trejtnar, P. Bovicelli, I. Proietti-Silvestri, R. Hrdina, L. Saso., Food Chemistry 135, 2584 (2012).

87. I. M. B. Rietjens, L. Haan, B. Spenkelink, H. M. Awad, N.H.P. Cnubben, J.J. van-Zanden, H. Woude, G.M. Alink, J.H. Koeman., Environmental Toxicology and Pharmacology 11, 321 (2002).

88. L. R. Fukumoto, G. Mazza, Journal of Agricultural and Food Chemistry 48, 3597 (2000).

89. J. Rodríguez, D. Contreras, C. Parra, J. Freer, J. Baeza, N. Durán, Water Science and Technology 40, 351 (1999).

90. J. Rodriguez, C. Parra, D. Contreras, J. Freer, J. Baeza, Water Science and Technology 44, 251 (2001).

91. D. Contreras et al., Journal of the Chilean Chemical Society 54, 141 (2009).

92. Z. S. Zhao, S. Khan, P. J. O’Brien, Biochemical Pharmacology 56, 825 (1998).

93. K. Jensen, C. Houtman, Z. Ryan, K. Hammel, Applied and Environmental Microbiology 67, 2705 (2001).

94. N. Perron, J. Brumaghim, Cell Biochemistry and Biophysics. 53, 75 (2009).

95. Z. Kerem, K. A. Jensen, K. E. Hammel, FEBS Letters 446, 49 (1999).

96. A. Paszczynski, R. Crawford, D. Funk, B. Goodell, Applied and Environmental Microbiology 65, 674 (1999).

97. K. Jensen, Z. Ryan, A. Vanden-Wymelenberg, D. Cullen, K. Hammel, Applied and Environmental Microbiology 68, 2699 (2002).

98. M. Monrroy, J. Baeza, J. Freer, J. Rodríguez, Bioremediation Journal 11, 195 (2007).

99. C. Oviedo, A. Berrocal, J. Navarrete, H. Mansilla, D. Contreras, Química Nova 35, 1772 (2012).

100. D. Contreras, Rodriguez, J., Basaez, L., Freer, J., Valenzuela, R., Mansilla, H., Vanysek, P., Water Science and Technology 64, 2103 (2011)

101. J. Xu, R. B. Jordan, Inorganic Chemistry 27, 1502 (1988).

102. V. Kristinová, R. Mozuraityte, I. Storrø, T. Rustad, Journal of Agricultural and Food Chemistry 57, 10377 (2009).

103. R. C. Hider, B. Howlin, J. R. Miller, A. R. Mohd-Nor, J. Silver, Inorganica Chimica Acta 80, 51 (1983).

104. B. Zhu, N. Kitrossky, M. Chevion, Biochemical and Biophysical Research Communications 270, 942 (2000).

105. B. Zhu, H. Zhao, B. Kalyanaraman, B. Frei, Free Radical Biology and Medicine 32, 465 (2002).

106. W. Ferraz, L. Oliveira, R. Dallago, L. Conceição, Catalysis Communications 8, 131 (2007).

107. V. S. Chedea, L. Choueiri, M. Jisaka, P. Kefalas, Food Chemistry 135, 1999 (2012).

108. L. Choueiri, V. S. Chedea, A. Calokerinos, P. Kefalas, Food Chemistry 133, 1039 (2012).

109. J. Pracht, J. Boenigk, M. Isenbeck-Schröter, F. Keppler, H. F. Schöler, Chemosphere 44, 613 (2001).

110. L. Friedrich, M.A. Mendes, V.O. Silva, C.P.S. Zanta, A. Machulek Jr. F.H. Quina, Journal of the Brazilian Chemical Society 23, 1372 (2012).

111. J. C. Danilewicz, American Journal of Enology and Viticulture 54, 73 (2003).

112. S. Arreguin, P. Nelson, S. Padway, M. Shirazi, C. Pierpont, Journal of 
Inorganic Biochemistry 103, 87 (2009).

113. D. Berg, M. Gerlach, M.B.H. Youdim, K.L. Double, L. Zecca, P. Riederer, G. Becker, Journal of Neurochemistry 80, 719 (2002).

114. I. Paris, P. Martinez-Alvarado, S. Cárdenas, C. Perez-Pastene, R. Graumann, P. Fuentes, C. Olea-Azar, P. Caviedes, J. Segura-Aguilar., Chemical Research in Toxicology 18, 415 (2005).
115. P. Hašková, P. Kovaříková, L. Koubková, A. Vávrová, E. Macková, T. Šimůnek., Free Radical Biology and Medicine 50, 537 (2011).

116. P. H. Black, L. D. Garbutt, Journal of Psychosomatic Research 52, (2002).

117. L. K. Charkoudian, K. J. Franz, Inorganic Chemistry 45, 3657 (2006).

118. W. Linert, G. N. L. Jameson, Journal of Inorganic Biochemistry 79, 319 (2000). 